\title{
The Method of Studying Administrative Law
}

\author{
${ }^{1} \mathrm{Xin} \mathrm{Xu}$ \\ ${ }^{1}$ Oxbridge College, Kunming University of Science and Technology, Kunming, Yunnan, China
}

Keywords: Administrative Law, Law Students, Method.

\begin{abstract}
Administrative law is a recognized course that is difficult to teach and study. The so-called "difficult", that is not easy to do, trouble, trouble. It is undeniable that the administrative law is indeed a course for teachers and law students to "get angry", to learn, is not easy, need to spend a lot of time and effort, and the correct learning methods. In our country law school, the content of administrative law course is complicated, the concept of abstract, teaching haste, teaching boring, often make the undergraduate students daunting.
\end{abstract}

\section{The Question is Raised}

According to the related files regulation of ministry of education, as a core course of law of administrative law, generally referred to as the "administrative law and administrative procedure law" (to everyday and make it easy for students, so called "administrative law"). Take our hospital as an example; the teaching time of administrative law course arrangement is for the second term of university, three hours a week, forty-eight class hours. With the research and development of administrative law teaching mode, many colleges and universities in China have made necessary adjustments to the content of administrative law teaching and scheduling. For example, many colleges and universities law schools divide "administrative law and administrative procedure law" into two courses: "administrative law" and "administrative procedure law", and add corresponding credits. In the second semester of junior year, some colleges and universities have specially opened the case study of administrative law and administrative procedure law. In the innovation of teaching mode of administrative law, the law schools of colleges and universities are "all kinds of things". In the administrative law course examination, course design and graduation thesis design, the administrative law examination results and the rate of achievement is relatively low. Most of the students "color change" talk about administrative law, interest in the study of administrative law is not big, lead to select as the course design and graduation thesis design direction in the field of administrative law students less, even if the administrative law as the design direction, study is just some of the basic problem of administrative law, often become a mere formality, the disadvantages in the superficial. In the annual national judicial exam, administrative law subjects scored fairly low. In the past years of judicial examination, the scores of administrative law subjects are kept at about 60 points, which cannot be ignored. Students generally feel that even if they pass the judicial examination, the impression of administrative law is still like sitting in a cloud. What is more, take the initiative to give up in the process of review judicial examination of the administrative law review, the reason is simple: "administrative law is so difficult, even if the review, also not necessarily does well, rather than spend a lot of time and energy on administrative law, it is better to spend time to the other certain branches of law". As far as I'm concerned, the high score by the judicial examination, but also admitted that he for the understanding and awareness of administrative law is still in extremely superficial level, for a lot of administrative law theory and practical problems or fog.

\section{The Research Achievements and Predicament of Administrative Law Teaching Mode}

China's administrative law research started late, but the development has been thirty-eight years, the administrative law of the general system has been from the building to mature, on the basis of increasingly perfect. Although the discussion of the scope of administrative law courses is far less 
enthusiastic as American scholars, there are some administrative law scholars who have made some useful attempts on administrative law teaching. In the administrative law case teaching has published a lot of study textbooks, such as: Professor Zhang Zhiyuan's "Administrative Law Case Analysis Course" (Peking University Press 2016 edition), judicial examples and administrative examples simultaneously, opened a comprehensive administrative law case teaching (The Renmin University of China 2010 edition), on the one hand, the basic principles of administrative law and the basic administrative legal system, on the other hand to develop students to analyze, think and solve the problem of ability , To improve the comprehensive quality of students of law students; Professor Yu Lingyun "Administrative Law Case Analysis and Research Methods" (Renmin University of China Press, 2008 edition), conscientiously collate, reflect the accumulated teaching experience and academic research, carefully combing cases in the administration The implementation of the law and the development of the theory of what kind of role, and the experience of the transfer to the students; Lin Hongchao associate professor of "Administrative Law and Administrative Procedure Law Case Study" (China University of Political Science and Law 2014), the knowledge system integrity, The election case is typical and readable. In the judicial practice unit is also no lack of administrative law case compilation and related monographs, has been formed practice, continued to publish. In addition, the major colleges and universities nationwide law school also according to their actual situation have opened administrative law and administrative procedural law case courses, and organized law school "elite" to prepare administrative law case teaching materials or report quality courses. It is true that we have achieved some results in the teaching of administrative law, but at the same time exposed the problem. From the administrative law curriculum set up point of view, many colleges and universities law school only set up "Administrative Law and Administrative Procedure Law" a course. As the content is complicated, teaching time is extremely limited, can only be selective teaching. In addition, the administrative law case teaching method is still in the exploratory and research stage, did not form a unified, mature teaching methods, many administrative law case teaching teachers are "feeling the stones across the river", the first course set up, and gradually And then explore the teaching methods and the appropriate teaching content. Even some law schools only to open and set up, seriously ignored the effectiveness of administrative law case teaching. Administrative law case teaching teachers there are serious shortage of the status quo, both administrative law, but also has the practical experience of administrative law teachers are rare. Most of the administrative law case teaching teachers can only rely on limited experience and administrative law theory of knowledge to teach, teaching methods confined to the basic principles of administrative law and administrative legal norms of interpretation, and related cases into the method is outdated, There is no new ideas at all, both boring, but also the lack of practicality, so that students can not mention the interest of learning. Over time, students did not improve, the teacher is only doing simple repetitive work. In addition, compared with the theoretical research of administrative law, the study of administrative law case teaching is seriously inadequate. In recent years, high level papers are less and less concerned. Administrative law case study seems to be entering the bottleneck, the problem is obvious, at a glance, but to fundamentally solve, is not easy. Law school of administrative law teachers even if the theory of deep foundation, but also difficult to deal with administrative practical problems of thin.

\section{The study of the method of administrative law}

\subsection{Establish system.}

Law students in the brain to establish a macro administrative law system, the formation of an administrative law system thinking, which is one of the basic conditions of the study of administrative law. Since the teaching law curriculum in September 2009 has been honed for eight years, the author has paid special attention to the cultivation and construction of students' administrative law system. On the one hand, to guide students to change the inherent way of thinking. For example: civil acts are mostly legal acts of both sides, respect for the expression of the true meaning of the main body of equality, and administrative acts are unilateral legal acts, with national will, legal, mandatory and executive. In private law, "no law can be prohibited"; in public law, "no law cannot be authorized." 
On the other hand, the student beginner administrative law should establish a kind of administrative law system thinking.

\subsection{Answer three questions.}

We have been actively thinking about three basic questions: first, what is the philosophical basis of administrative law? Second, the relationship between administrative law and the rule of law? What kind of administrative law does China need? The first question is: the philosophical basis of Chinese administrative law is not the right standard (control theory), it is not the power standard (management theory), but the balance theory of power and right interaction. The interpenetration of public law and private law, the interaction and balance between executive and civil rights and the balance between procedural justice and substantive justice. In other words, the foundation of administrative law is not a priority of citizens, nor is it a priority of the government, but the rights and powers of citizens and government, and coordination and interaction. The second problem is that the key to the rule of law is the construction of the government of the rule of law, while the key to the construction of the rule of law lies in the administration of the law, which is the core issue of administrative law. The rule of law is not only governed by law, but also by law. The rule of law is the limitation of power. The power of the government should also be restricted by the law, which is the essence of the rule of law. The government must abide by the law, which is the true meaning of the rule of law. The third problem: China needs to have inherited administrative law, realistic administrative law, constantly updated administrative law and administrative law in learning. Of administrative law in China to go his own way, to touch the stones across the river, the outstanding achievements of predecessors', based on the realistic national conditions, summarizing the new experiences, draw lessons from the advanced technology, have the courage to self-improvement and transformation, geared to the needs of modernization.

\subsection{Familiar with the principle.}

Law students should be good at understanding, familiar with the basic principles of administrative law, especially the core principles. The basic principle of administrative law is the unique principle of administrative law, with independent theoretical system, grasp the basic principles of administrative law essential to master the essence of administrative law. For example: administrative law to study public administration, rather than study the general administration, which is the basis of the principles of administrative law. Public administration refers to the specific activities of administrative subjects to participate in administrative legal relations, to manage state affairs and social affairs, and to produce legal effects. And general administration refers to all management-related activities. The former is the basic category of administrative law research, the latter is the scope of other departmental law research. Analysis of a case or legal action, the starting point is from the "public administration" began. In addition, the law students should also bear in mind the basic principles of the principle of administrative legitimacy, that is, the administrative body should exercise their powers according to law. In other words, the only behavioral model of the administrative subject can only be administrated according to law, and there is no other choice.

\subsection{Lapping method.}

November 1, 2014, the 12th session of the 11th meeting of the standing committee of the National People's Congress passed the on modifying the < administrative procedure law of the People's Republic of China > decision ", come out for a long time of administrative procedure law revision finally ushered in the birth for the first time in 25 years. Our country is a statute law country, but is difficult to form a unified administrative law from the form of administrative law code, the reason is that: the materials of administrative law in our country, to a wide range, substantive law and procedural law exists in the same law of normative documents; In addition, the whole country, large and small normative documents "dazzling" and "overwhelming", did not form the necessity and operability of the uniform administrative code. The situation makes it difficult to read all the administrative rules, but only the master method is the way to learn administrative law. Study the administrative law to pay attention to the method: first, should make functional orientation to the 
administrative law bar, understand its goal pursue. Second, mastering the key law is the key to learn administrative law well. In particular, the newly revised law is particularly important, and the newly revised law is often a hot topic in the society, and the way to revise the law is also a response to the needs of social development. There is no doubt that the newly revised law is the focus of learning, and the new and old contrast memory and understanding are better.

\subsection{Familiar with the case.}

No reading and analysis of the case, the light is sitting in the classroom from learning, indifferent to the reality of the case, the real meaning cannot be properly interpretation of administrative law. In the process of teaching and learning, teachers and students can choose the Supreme People's court "bulletin" published regularly in judicial cases, can also choose the Supreme People's court administrative tribunal or the grass-roots court administrative tribunal compiled a collection of cases, can also choose the current social hot cases. The "case shortage" of administrative law has been gradually broken, but the selection and analysis strategy of relevant cases has become a new problem. It is recommended that you learn the classic cases, and learn from other similar cases. The analysis of administrative cases should conform to the basic logic and characteristics of administrative law, for example, the legitimacy analysis and rationality analysis of administrative law is the basic analysis angle. In a word, studying administrative law cases is one of the important contents of studying administrative law.

\subsection{Reading classic.}

In our country, administrative law is still a young discipline. Compared with civil law, criminal law and other disciplines, the development of administrative law is also a long way to go. For the law students, not only to master the basic theory of textbooks and related laws, but also should read the classic works at home and abroad. Personally, the study of classics can not be confined to administrative law, but also should be involved in other related areas of the work. Whether it is civil law in Germany, France, Japan, or the Anglo-American law of the United States, Britain, have a complete administrative legal system, their theory and experience worthy of our learning and reference. Reading is one of the most convenient and efficient ways to understand our country. For example: Otto Meyer's "German Administrative Law", Yano Hiroshi's "Administrative Law", Professor Gong Xiangrui's "Comparative Constitution and Administrative Law", Professor Wang Mingyang's "Trilogy": "British Administrative Law" "French Administrative Law" and "US Administrative Law" and so on. As well as other areas of the book: Burman's "law and religion", Fuller's "legal morality" and so on. In theory, do some comparison, expand our vision and depth. In practice, we need to continue to gain experience, but the physical intention, the spirit of the weak and distress, but also makes us have to get rid of the inherent vulgar and superficial. Only reading, in order to achieve self-sublimation.

\subsection{Pay close attention to practice.}

Professor zhi-yuan zhang said: "if the lapping law is a study focusing on the legislature, familiarity is case study focuses on the judicial organ, then observe the practice (hotspot) is the study focused on the administrative organ. The traditional administrative jurisprudence overemphasizes the formal legality of administrative activities and the judicial protection of individual rights. As Arnold answer students' questions: "in the classroom, we can discuss without doing, analyzes the behavior of the judge, but once you add black body, sitting high above the court, was honored for your, you have to believe that you are in according to some objective standards". "Some objective criterion" is a practice standard, an experience, habit and tradition in administrative practice. Administrative law is not only a part of the law but also a part of society and is a part of tradition and culture.

\section{Conclusion}

Administrative law is not only a theoretical course, but also a highly practical course. On the law students, not only to lay a solid theoretical knowledge, but also participate in administrative practice, 
the judicial practice and the practice of decision-making. In order to improve the law students learning interest and learning ability of the administrative law, we must pay attention to the administrative law case teaching. The case teaching of administrative law can provide us with an insight into the principle of administrative law, and improve our ability to use administrative law in order to break the dilemma of the "blackboard" administrative law teaching mode. This book is the author for many years, engaged in the teaching of administrative law experience and summary, hoping to bring some help and inspiration to the majority of learners.

\section{References}

[1] Zhang Zhiyuan: "Law students administrative law case teaching model research", contained "Journal of Henan University of Finance and Economics" 2013 the third period.

[2] Zhang Nengbao editor: "judicial examination over the years that test sites classified Jiejing: Administrative Law and Administrative Procedure Law", Law Press, published in 2016.

[3] Gao Qinwei translation: "administrative law teaching thinking: look forward to sequel", contained "administrative law research" 2006 fourth period.

[4] Chen Xiaowen: "the philosophical basis of administrative law", Peking University Press, January 2009 edition.

[5] Liang Zhiping: "Discrimination", Guangxi Normal University Press, April 2015 edition.

[6] Peter De Enrico, edited by Deng Zhipan: "Front of Law", Peking University Press, published in July 2012. 